\title{
Relationship Between Parents' Attitude Towards their Children's Education and Level of Students' Discipline in Public Secondary Schools in Naivasha Sub-County, Kenya.
}

\author{
Goodeve S.K Mwaniki ${ }^{1}$, Prof. J. Kanjogu Kiumi ${ }^{2}$, Dr. M. Ngunjiri ${ }^{3}$
}

Department of Curriculum and Education Management, Laikipia University, Kenya.

\begin{abstract}
The purpose of this study was to assess the relationship between parents' attitude towards their children's education and level of students' discipline in public secondary schools in Naivasha sub-county, Kenya. The study targeted a total of 197 respondents (constituting 28 head teachers and 169 teachers). A total of 195 respondents participated in the study (169 teachers and 26 principals) participated giving a response rate of $99 \%$. Purposive sampling technique was used to sample head teachers while Krejcie and Morgan's (1970) table for determining sample size for teachers. Questionnaires were used as instrument for data collection. SPSS was used to analyze the data where both descriptive and inferential statistics were used. The analyzed data were presented in terms of graphs and tables. The results showed that there was a significant positive relationship between parents' attitude towards child's education and students' discipline $(\mathrm{r}=.399, \mathrm{p}=.000)$. Therefore, the null hypothesis that there was no significant relationship between parents' attitude towards child's education and students' discipline was rejected at .05 level of confidence. The study therefore concluded that parents' attitude towards child's education influences students' discipline in secondary schools in Naivasha sub-county. It was recommended that parents' should have more positive attitude towards a child's education. This can be realized through monitoring the academic performance of their children and taking keen concern on decline on the performance by engaging teachers.
\end{abstract}

Key Words: Parents' attitude, children's education, students' discipline.

\section{INTRODUCTION}

Education has received unmatched attention as the best method of achieving a country's economic and social growth. It is the living bud of a nation's development (Muchemi, 2005). If a nation wishes to achieve any form of development, her people must be well socialized though a defined education system. It is through the education system that nations impart to their people the aspirations that will produce the citizens of their choice. The Kenyan government together with other stakeholders in education within and outside the country has invested heavily in education. Consequently, notable achievements have been realized in the country in regards to students' enrolment at all levels educations. For instance, at the secondary level of education, enrolment stood at $1,472,600$ in 2009. In 2014, enrolment had increased to 2,331,700 representing a 58\% increase rate within a period of five years. There has also been an upward trend in Gross Enrolment Ratio (GER) and Net Enrolment Ratio (NER) in the Country at the secondary level of education. For instance, GER and NER at this level of education increased $16.4 \%$ and $14.3 \%$ respectively between 2009 and 2014 (MOEST, 2014).

The introduction of Free Primary Education (FPE) in 2003 resulted in increased enrolments in the primary schools and later in the subsequent secondary sub-sector. The period from 2003 therefore, has seen tremendous progress in the secondary sub-sector ranging from infrastructural and enrolment expansion to increased participation and transition rates (Republic of Kenya, 2009). For instance, there were a total of 5,019 public secondary schools in 2009. In 2014, there were a total of 7,686 secondary schools signifying an increase of 53\% (MOEST, 2014). This progress has been realized through the efforts of the government through initiatives like the Constituency Development Fund (CDF) and Local Authority Transfer Fund (LATF). Local communities and other Donor agencies have also helped in the expansion efforts of the educational institutions. 
Education is widely valued across the world as a central factor in economic, political, and social development of any country (Republic of Kenya, 2012). The Constitution of Kenya 2010 articles 43.1f, 53.1b and 55a makes education a right of every Kenyan while the Kenya Vision 2030 underscores the importance of education in ensuring relevant human and social capital for sustainable development (Government of Kenya, 2010). In particular, the Constitution guarantees every child to free and compulsory basic education. It further provides for access to affordable tertiary education, training and skills development. According to the Bill of Rights 2010, basic education is a fundamental human right. Despite the importance of basic education, there are a number of challenges facing its implementation and the realization of its goals (Government of Kenya, 2010). Among the challenges to the realization of the goals of secondary education is indiscipline among students. This is because students' discipline does not only provide a sense of dissention among learners and hence commitment to school values, but also has an influence on teachers' job satisfaction, motivation and consequently commitment to students and students learning (Imber \& Neidt, 1990). This observation has the implication that in a school environment where students' level of discipline is low, learning achievement may undoubtedly be compromised. In Naivasha Sub-County, where the study was executed, a total of 7 schools experienced unrest between 2010 and 2015 which translated to $25 \%$ of the total number of secondary schools in the Sub-County (Naivasha Sub-County Education Office, 2015).

Several studies have been carried out to determine the causes of students' indiscipline in schools. A majority of the studies have tended to show that unfavorable home and school based factors are critical antecedents to students' indiscipline. For example, Lockheed (1991) observed that an orderly school environment is closely linked with schools where teachers gain and hold the attention of their students, maintain discipline, begin and end lessons on time and evaluate student performance regularly. Muchemi (2006) observed that a school environment that is safe, peaceful and free from student riots should be the effort of all the school management fraternity.

Eshiwani (2009) asserted that students' strikes are a symptom of inability of the schools to cultivate relevant morals among the youth and this situation threatens socio-economic development of the nation. According to Masese (2007), the result of student strikes include incidences such as rape, violence, loss of school property, loss of lives and loss of school time due to frequent closures. This in turn leads to poor examination performances and also wastage of potential human resources due to expulsion of students who may be linked to such disturbances. From this premise, it is clear that discipline is essential to smooth functioning of schools and the society at large.

Etizi (2008) defines discipline as a system of making the individual to make reasonable decision responsibly. Etizi further says that the goal of discipline is to make it possible for the individual or a team of individuals to succeed in the set goals. The term therefore denotes the kind of order involved in the efforts by trying to reach appropriate standards to follow appropriate rules for engaging in a valid activity. It requires freedom of choice and makes one to understand the consequences and is not imposed by authority figures but rather individual themselves (Charles, 1995). Therefore, with discipline in our learning institutions, we would have very rare cases of the student strikes. Griffin (1994) asserts that sound discipline is an essential ingredient in the creation of a happy and industrious school community, performing properly its function of training the citizens of tomorrow. Based on this background, this study therefore sought to find out whether there is any relationship between parents' attitude towards children's education and level of students' discipline in schools.

\subsection{Statement of the Problem}

As it has been pointed out in the background part of the study, students' indiscipline in Kenyas' secondary schools is depicting a worrying trend. This is because; hardly a school term passes without incidents of indiscipline being reported in the mass media. This has the implication that if this behaviour trend goes unchecked, our secondary schools may not play their role expectations of producing responsible citizens. Evidence adduced from studies within and outside Kenya seems to suggest that unfavourable school and home environments are critical risk factors to students' misdemeanor. This study therefore sought to find out whether there is any relationship between parents' attitude towards children's education and level of students' discipline in public secondary schools in Naivasha sub-county, Kenya. 


\section{II: LITERATURE REVIEW}

This section presents the theory used in the study and the relevant literature on the relationship between parents' attitude towards their children's education and level of students' discipline and the theory used in the study.

\subsection{Theoretical Framework}

Rohner theory of socialization and Baumrid theory of parenting styles were used in this study. Rohner theory of Parental acceptance-rejection commonly known as a theory of socialization. This theory focuses on four major issues, i.e. behavioral, cognitive and emotional development of children and adult personality functioning. Every individual has experienced the warmth and affection provided to him/her by someone important, who is called the parent not necessarily, mother and father. This warmth and affection is a range from a great deal to none, where one end is parental acceptance while the other one is rejection (as cited in Hussain \& Munaf, 2012). Two dimensional model of parenting: warmth-hostility and restrictivenesspermissiveness was presented by Becker, high in warmth and restrictiveness Parents produce complaint, well-behaved children, whereas those high in warmth and permissiveness promote socially outgoing, independent, and creative children ( as cited in Khalid, 2004).

Baumrind (1966) theoretical model of parenting style which included the nurturance and control dimensions of child rearing into a conceptualization of parenting style that was fastened in an emphasis on parents' belief system (Darling \& Steinberg, 1993). For Baumrind, key element of parental role is to socialize the child to conform to the necessary demands of others and maintaining a sense of personal integrity. She defined control as strictness, use of corporal punishment, consistency of punishment, use of explanations, and so on (Baumrind, 1966). In contrast, Baumrind argued that parents' willingness to socialize their child is conceptually separate from parental restrictiveness. Rohner theory of socialization and Baumrid theory of parenting styles were used in this study to explain the influence of parents' attitude towards child's education on discipline in schools.

\subsection{Parental Commitment to Children's Education and School in General}

Parental attitude is a measure or an index of parental involvement. A child, brought up with affection and care in the least restrictive environment would be able to cope up better with the sighted world. Therefore, the family shapes the social integration of the child more than a formal school. Turnbull (1983) has identified four basic parental roles- parents as educational decision makers; parents as parents; parents as teachers and parents as advocates. Since the parent's attitude is so important, it is essential that the home and school work closely together, especially for children with disabilities. The Warnock Report (1978) stresses the importance of parents being partners in the education of their children. The role of parents should actively support and enrich the educational processes.

Tait (1972) opines that the parents' psychological well-being and the ease or difficulties with which they decipher the cues that facilitate the socialization process influence the personal and social development of the child. It is the parents who exert the major influence on the development of the child from birth to maturity. One of the most important attributes of parental attitude is consistency. As children mature into adolescence, family involvement in their learning remains important. Family involvement practices at home and at school have been found to influence secondary school students' academic achievement, school attendance, and graduation and college matriculation rates (Dornbusch \& Ritter, 1988). Despite its importance, however, families' active involvement in their children's education declines as they progress from elementary school to middle and high school. Research suggests that schools can reverse the decline in parent involvement by developing comprehensive programs of partnership (Epstein, 1989).

Bogunovic and Polovina (2007) found in a study that the family stimulation is the resultant of the influence of cultural and educational profile of the family and active parental attitudes regarding education and attainment of their children. They examined the students' attitudes towards schooling, and to obtain answers to the question: which stimulating aspects of family context are the most predictable for the development of educational aspirations, i.e. attitudes towards school and gaining knowledge, educational interests and plans for further education. The sample consisted of 1.464 eighth-grade sample students, aged 15, from 34 primary schools in Serbia. The data were collected by the use of questionnaires filled in by the students and school principals. The results indicated a trend of interrelatedness of cognitively and educationally favorable conditions within the family and positive attitudes towards school, attainment, high 
aspirations and cognitive and intellectual interests for out-of-school activities.

Quilliams and Beran (2009) found that the more parents are involved in the school and actively promote learning at home, the higher the student's grades. In the same study, when children's perceptions were considered, those who perceived that their parents had positive attitudes towards education and took interest in the school had higher achievement. In a study focusing on early elementary students and how different levels of parental involvement affected achievement, it was found that quality of instruction at the home, involvement in school, and parental expectation (all from the mother) had a higher impact on children's achievement in third grade than the child's IQ, educational level of the mother, and the student's achievement history (Englund et al., 2004).

A number of studies have been carried out with regard to youth rebellion to authority in the home, school and societal fronts. An example is Kabiru (2006) who emphasizes the need for parents to instill discipline in their children at the family level. He observes that parents contribute to children's indiscipline in many ways; by being bad role models and by avoiding parental responsibilities such as teaching their children good behaviour. This rebellion was manifested in the groups or gangs the youth formed to show solidarity in defying the school or societal expectations. The same kinds of groups were formed in schools causing problems in the discipline system of the school. In Kenya, as in many growing economies, youth indiscipline was on the increase.

Deepshika \& Bhanot (2011) in their study to assess family environment and its impact on their social emotional adjustment revealed that eight family environment factors, viz. cohesion, expressiveness conflict, acceptance and caring, independence, active-recreational orientation, organization and control together showed significant role in socioemotional and educational adjustment of the adolescent girls. When schools believe that lax parental discipline explains a child's misbehavior, educators are less likely to consider alternative explanations for the misbehavior and the full range of interventions that could be implemented at school (Greene, 2011). Osher, Bear, Sprague \& Doyle (2010) stated that the three approaches viz. ecological approaches to classroom management, school wide positive behavioural supports and social and emotional learning improves school discipline practices and student behavior.
Felix (2011) asserts that many school problems cannot be dealt with in isolation. Various family circumstances may exert more powerful influences over learner's behavior than anything that happens in school. Lack of discipline among learners is largely a reflection of attributes, values and practices of their society. If there is no social order in society, learners will be indisciplined in school (Grossincle, 1990). Discipline problems reflect problems in the home. Schools are microcosm of society, as problems like drug abuse, crime and physical abuse increase in society, so will the discipline problems in schools (Lochan, 2010). Thus, since schools exist as societal institutions they are bound to be influenced by whatever transpires outside them. A variety of family factors mediate classroom disruptive behavior.

Bryk and Schneider (cited in Sanders \& Sheldon, 2009) maintain that schools become successful when a strong and positive relationship among students, parents, teachers and the community has been established. All students are more likely to experience academic success if their home environment is supportive (Sanders \& Sheldon, 2009). The benefit for students of a strong relationship between schools and homes is based on the development of trust between parents and teachers. According to Bryk and Schneider (cited in Muscott, Szczesiul, Berk, Staub, Hoover, \& PerryChisholm, 2008), this trusting relationship occurs when teachers and parents respect one another and believe in the ability of the other person and his or her willingness to fulfill their responsibilities.

According to the Department of Education (2004) in the United States, studies have shown that students with involved parents are more likely to earn higher grades, pass their class and be promoted, they are more likely to attend school regularly and graduate and go on to postsecondary education, irrespective of their socio-economic status. Trusty (cited in Henderson \&Mapp, 2002) concurs with this, and claims that the level of parental involvement in high school influences the students' expectations to finish college. In addition, Obeidat and Al-Hassan (2009) maintain that not only do children with involved parents gain academically, but they are also more likely to show improved behaviour and to have better social skills.

An effective form of involvement is presented by Epstein's model. Epstein (2009) discusses how children learn and develop through three overlapping "spheres of influence:" family, school, and community. These three spheres must form 
partnerships to best meet the needs of the child. Epstein defines six types of involvement based on the relationships between the family, school, and community: parenting (skills), communicating, volunteering, learning at home, decision making, and collaborating with the community. Epstein emphasizes that all of these six types of involvement need to be included to have successful partnerships.

Another effective form of involvement presented by Hoover-Dempsey and Sandler (1995) includes out of school or home-based partnerships as well as school-based activities with parents and children. They discuss that when parents get involved (going to school events, helping with homework) children's schooling is benefited. Benefits include knowledge, skills, and confidence.

Weiss, Caspe and Lopez (2006) believe that children must have a range of learning environments around them, or complementary learning. Such learning environments include family, early childhood programs, schools, out-ofschool time programs and activities, libraries, museums, and other community-based institutions. Weiss et al. believes that complementary learning will provide a linking of consistent learning and development. This linkage is similar to that of Epstein's (2001) spheres of influence. Weiss et al. linking of community and Epstein's spheres of influence are similar that they each incorporate community, school and family so that they all affect one another.

According to Cotton (2001) there are signs that the most effective forms of parental involvement are those where parents' work directly with their children. Programs that show the most effective results include tutoring, working on homework with children, and reading with children. These active forms of parental involvement have had a greater impact on achievement than passive forms of involvement. Passive forms of parental involvement have still been shown to improve children's achievement, so they are better than no parental involvement at all. Cotton expresses another effect of parental involvement when the parent intervenes at an early age. The earlier in a child's life that the parents become involved, the greater the effects will be on the child's educational process.

According to study done by Reutzel and Cooter (1996) positive effects on parental involvement were shown to increase when choices were provided to the parents. The schools that offered a variety of ways for parents to get involved had an increased effect on student achievement. Giving parents various methods or activities to involve them in their children's lives, increased the willingness and ability of parental involvement. This increase in parental involvement has shown a consistent, positive relationship in students' achievement and development in school.

According to Hoover-Dempsey and Sandler (1995), parents agree that they have an important role to play in home-based activities when it comes to children's learning. These home-based activities include, among others, monitoring their child's school work and progress, discussing school related issues with their child and assisting with homework. Furthermore, research has shown that of all the different types of parental involvement, parents report that helping their children with homework is particularly effective for enhancing their academic achievement. According to the Department of Education in the United States (cited in Patall, Cooper \& Robinson, 2008), parent behaviour appears to corroborate this belief, $90 \%$ of parents report setting aside a place for homework, and $85 \%$ of them report checking to see that homework has been done.

Students generally feel that when parents help, they do better at school. In a study by Balli (cited in Patall, Cooper \& Robinson, 2008), 95\% of students reported that they did better in school at least some of the time when they received help with homework from their parents. Williams et al. (cited in Desforges \& Abouchaar, 2003) carried out research in 2002, among English students between the ages of five and sixteen. Their findings show that $71 \%$ of parents of children in their first year in school considered themselves to be involved in their children's homework. This participation declined steadily with each grade, and by grade eleven, only $1 \%$ of parents considered themselves to be involved with their child's homework.

\section{III: METHODOLOGY}

This study was carried out in public secondary schools in Naivasha Sub-county of Nakuru County, Kenya. The Sub-County has 28 public secondary schools. Ex-post facto research design was used in the study. The target population for the study compromised head teachers and teachers of public secondary schools in Naivasha Sub-county. The population for the study was 314 subjects comprising 28 principals and 286 teachers. The study targeted a total of 197 respondents (constituting 28 head teachers and 169 teachers). A 
total of 195 respondents participated in the study (169 teachers and 26 principals) participated giving a response rate of $99 \%$. Principals were purposively selected for the study while teachers were sampled based on Krejcie and Morgan's (1970) table for determining sample size (n) from a given population $(\mathrm{N})$. A total of 169 teachers (n) were sampled from a total population of 286 teachers $(\mathrm{N})$ in the study area. Data was collected through a selfadministered questionnaire. Two sets of questionnaires, one for head teachers and the other for teachers were used to collect the data. The scoring in the questionnaire was done using a tick against the statement given in scale from definitely true, true, undecided and definitely not true. Primary data from the field were edited to minimize errors made by respondents. Coding was done to translate question responses into specific categories. The coded items were analyzed with the aid of a computer on SPSS. Normal scale data, specifically data on respondents and school characteristics were analyzed using frequency counts and percentages. Descriptive statistics such as frequencies and percentages were used while inferential statistics such as chi-square was used to test the relationships between the study variables.

\section{FINDINGS OF THE STUDY}

This section presents the findings of the study on the relationship between parents' attitude towards children's education and level of students' discipline in public secondary school in Naivasha sub-county, Kenya.

\subsection{Level of Students' Indiscipline As Reported by Principals and Teachers}

To establish the level of students' indiscipline, teachers and principals were asked to indicate the level of students' indiscipline in their schools. The findings are as presented Figure 1.

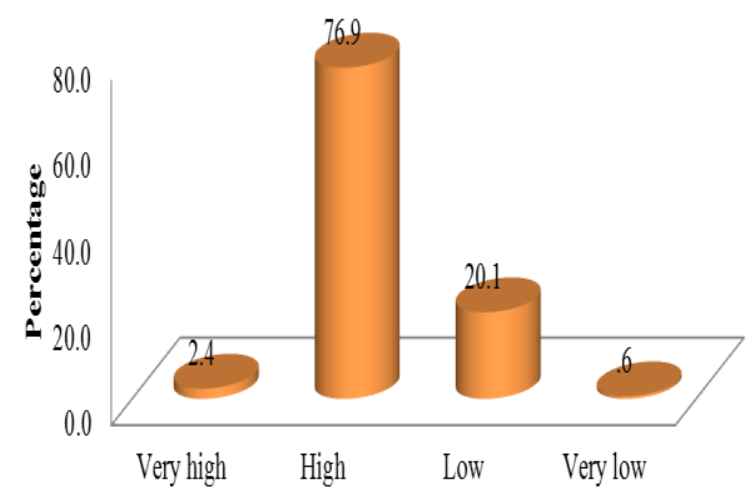

Source: Field Data (2017)
Figure 1: Level of Students' Indiscipline in Secondary Schools in Naivasha Sub-County

As is clearly shown in figure 1 , an overwhelming majority of teachers $(76.9 \%)$ reported that their students discipline was high. They were followed by $20.1 \%$ of teachers who indicated that students' level of discipline in their schools was low. Very few of the teacher respondents $(2.4 \%)$ reported that students' level of discipline in their schools was very high. Similarly, only $6 \%$ of the teacher respondents indicated that the level of students' discipline in their schools was very low.

\subsection{Parents' Attitude Towards Children's Education}

Responses to the Likert scale items on parents' attitude towards children's education were analyzed. This was accomplished by adding respondents' scores for each item and dividing by the number of respondents $(\mathrm{n}=$ number of teachers). The mean scores are presented in Table 1 .

Table 1: Parents' Attitude Towards Children's Education

\begin{tabular}{l} 
Statement \\
\hline Failure by some parents to partner \\
with schools during initiation and \\
implementation of programs to \\
upscale students' academic \\
performance \\
Tendency by some parents to have \\
low premium on their children \\
education and success in school \\
Tendency by some parents to uphold \\
the view that their role is not \\
essential in regard to successful \\
progression of their children in \\
school \\
Tendency by some parents to have a \\
low respect for teachers and school \\
in general \\
Failure by some parents to report to \\
teachers on any detected/noted signs \\
of declining academic commitment \\
by their children \\
Source: Field Data (2017) \\
A look at the data shown in table 1 demonstrates \\
that the highest rated parents' attitude towards \\
children's education was failure by some parents to \\
partner with schools during initiation and \\
implementation of programs to upscale students \\
academic performance (mean 2.73), tendency by \\
some parents to have low premium on their children \\
education and success in school (mean 2.72 ), \\
tendency by some parents to uphold the view that \\
\end{tabular}


their role is not essential in regard to successful progression of their children in school (mean 2.57) and tendency by some parents to have a low respect for teachers and school in general (mean 2.49). The least rated parents' attitude towards children's education was failure by some parents to report to teachers on any detected/noted signs of decliningacademic commitment by their children (mean 1.98).

\subsection{Hypothesis test on Parents' Attitude Towards Children's Education and Students' Discipline}

The objective of the study was to establish whether there is any statistically significant relationship between parents' attitude towards child's education and students' discipline in public secondary schools in Naivasha sub-county, Kenya. In order to achieve this objective, the following null hypothesis was formulated and stated as follows:

H01: There is no statistically significant relationship between parents' attitude towards a child's education and students' discipline in public secondary schools in Naivasha subcounty, Kenya.

The findings, therefore, presumed that parents' attitude towards child's education is not linked to students' discipline. To ascertain the truth of this preposition, the hypothesis was tested usingdata generated from likert scale findings as presented in Table 2 and Pearson correlation coefficient in Table 3.

Table 2: Parents' Attitude towards Children's Education and Students' Discipline

\begin{tabular}{|c|c|c|c|c|c|c|c|c|c|c|c|c|c|c|c|c|c|}
\hline $\begin{array}{l}\text { Teac } \\
\text { hers }\end{array}$ & $\mathbf{Y}$ & $\mathbf{X}$ & $\begin{array}{l}\text { Teac } \\
\text { hers }\end{array}$ & $\mathbf{Y}$ & $\mathbf{X}$ & $\begin{array}{l}\text { Teac } \\
\text { hers }\end{array}$ & $\mathbf{Y}$ & $\mathbf{X}$ & $\begin{array}{l}\text { Teac } \\
\text { hers }\end{array}$ & $\mathbf{Y}$ & $\mathbf{X}$ & $\begin{array}{l}\text { Teac } \\
\text { hers }\end{array}$ & $\mathbf{Y}$ & $\mathbf{X}$ & $\begin{array}{l}\text { Teac } \\
\text { hers }\end{array}$ & $\mathbf{Y}$ & $\mathbf{X}$ \\
\hline 1 & 14 & 56 & 30 & 12 & 48 & 59 & 14 & 56 & 88 & 15 & 47 & 117 & 13 & 55 & 146 & 15 & 20 \\
\hline 2 & 14 & 56 & 31 & 7 & 52 & 60 & 7 & 51 & 89 & 16 & 44 & 118 & 14 & 56 & 147 & 15 & 55 \\
\hline 3 & 14 & 56 & 32 & 7 & 51 & 61 & 14 & 56 & 90 & 13 & 51 & 119 & 14 & 56 & 148 & 15 & 57 \\
\hline 4 & 14 & 56 & 33 & 7 & 51 & 62 & 14 & 57 & 91 & 17 & 50 & 120 & 14 & 56 & 149 & 19 & 55 \\
\hline 5 & 19 & 57 & 34 & 7 & 51 & 63 & 19 & 56 & 92 & 14 & 56 & 121 & 14 & 56 & 150 & 19 & 55 \\
\hline 6 & 14 & 42 & 35 & 7 & 51 & 64 & 7 & 51 & 93 & 13 & 48 & 122 & 17 & 30 & 151 & 14 & 56 \\
\hline 7 & 17 & 30 & 36 & 7 & 51 & 65 & 7 & 51 & 94 & 7 & 51 & 123 & 17 & 30 & 152 & 14 & 56 \\
\hline 8 & 17 & 30 & 37 & 7 & 51 & 66 & 7 & 51 & 95 & 14 & 56 & 124 & 7 & 51 & 153 & 9 & 56 \\
\hline 9 & 17 & 30 & 38 & 7 & 51 & 67 & 7 & 48 & 96 & 13 & 53 & 125 & 7 & 55 & 154 & 16 & 30 \\
\hline 10 & 17 & 30 & 39 & 7 & 51 & 68 & 7 & 51 & 97 & 15 & 53 & 126 & 7 & 51 & 155 & 15 & 43 \\
\hline 11 & 17 & 30 & 40 & 7 & 51 & 69 & 7 & 51 & 98 & 17 & 28 & 127 & 7 & 58 & 156 & 13 & 65 \\
\hline 12 & 17 & 34 & 41 & 7 & 51 & 70 & 7 & 51 & 99 & 14 & 50 & 128 & 7 & 51 & 157 & 16 & 37 \\
\hline 13 & 17 & 30 & 42 & 7 & 51 & 71 & 7 & 51 & 100 & 14 & 44 & 129 & 7 & 51 & 158 & 19 & 43 \\
\hline 14 & 17 & 30 & 43 & 7 & 51 & 72 & 7 & 51 & 101 & 16 & 27 & 130 & 23 & 17 & 159 & 10 & 27 \\
\hline 15 & 17 & 30 & 44 & 7 & 51 & 73 & 7 & 51 & 102 & 13 & 52 & 131 & 22 & 49 & 160 & 8 & 49 \\
\hline 16 & 17 & 31 & 45 & 7 & 51 & 74 & 7 & 51 & 103 & 13 & 50 & 132 & 20 & 46 & 161 & 11 & 31 \\
\hline 17 & 17 & 30 & 46 & 7 & 51 & 75 & 7 & 51 & 104 & 18 & 56 & 133 & 18 & 34 & 162 & 7 & 48 \\
\hline 18 & 17 & 30 & 47 & 7 & 51 & 76 & 14 & 53 & 105 & 18 & 49 & 134 & 18 & 34 & 163 & 7 & 51 \\
\hline 19 & 17 & 30 & 48 & 7 & 51 & 77 & 14 & 46 & 106 & 9 & 51 & 135 & 13 & 29 & 164 & 7 & 30 \\
\hline 20 & 17 & 30 & 49 & 7 & 51 & 78 & 19 & 53 & 107 & 18 & 46 & 136 & 19 & 45 & 165 & 7 & 30 \\
\hline 21 & 17 & 27 & 50 & 7 & 51 & 79 & 7 & 51 & 108 & 11 & 52 & 137 & 19 & 31 & 166 & 17 & 30 \\
\hline 22 & 17 & 30 & 51 & 7 & 51 & 80 & 7 & 51 & 109 & 11 & 51 & 138 & 12 & 55 & 167 & 7 & 51 \\
\hline 23 & 7 & 52 & 52 & 7 & 51 & 81 & 7 & 51 & 110 & 18 & 50 & 139 & 21 & 55 & 168 & 7 & 51 \\
\hline 24 & 7 & 51 & 53 & 7 & 51 & 82 & 7 & 51 & 111 & 15 & 39 & 140 & 16 & 38 & 169 & 7 & 51 \\
\hline 25 & 7 & 51 & 54 & 7 & 51 & 83 & 7 & 51 & 112 & 18 & 39 & 141 & 13 & 45 & & & \\
\hline 26 & 7 & 51 & 55 & 7 & 51 & 84 & 7 & 51 & 113 & 8 & 41 & 142 & 13 & 45 & & & \\
\hline 27 & 7 & 51 & 56 & 7 & 51 & 85 & 7 & 51 & 114 & 18 & 55 & 143 & 18 & 47 & & & \\
\hline 28 & 7 & 51 & 57 & 14 & 56 & 86 & 11 & 57 & 115 & 13 & 60 & 144 & 13 & 34 & & & \\
\hline 29 & 7 & 50 & 58 & 15 & 53 & 87 & 11 & 40 & 116 & 13 & 39 & 145 & 14 & 52 & & & \\
\hline
\end{tabular}

Source: Field Data (2017)

$\mathrm{X}=$ Students discipline

$\mathrm{Y}=$ Parents' attitude towards Child's Education 
Table 3: Correlation Between Parents' Attitude Towards Children's Education and Students Discipline

\begin{tabular}{lll}
\hline & $\mathrm{R}$ & $\mathrm{P}$ \\
\hline Pearson & .399 & .000 \\
Coefficient & & \\
No of Valid & 169 & \\
Cases & & \\
\hline
\end{tabular}

Source: Field Data (2017)

Table 3 shows that there was a significant positive relationship between parents' attitude towards child's education and students' discipline $(r=.399$, $p=.000)$. Therefore, the null hypothesis that there was no significant relationship between parents' attitude towards child's education and students' discipline was rejected at .05 level of confidence. It can therefore be concluded that parents' attitude towards child's education influences students' discipline in schools.

The findings of this study are in line with that of Turnbull (1983) who identified four basic parental roles- parents as educational decision makers; parents as parents; parents as teachers and parents as advocates. Since the parent's attitude is so important, it is essential that the home and school work closely together, especially for children with disabilities. Bogunovic and Polovina (2007) found in a study that the family stimulation is the resultant of the influence of cultural and educational profile of the family and active parental attitudes regarding education and attainment of their children. They examined the students' attitudes towards schooling, and to obtain answers to the question: which stimulating aspects of family context are the most predictable for the development of educational aspirations, i.e. attitudes towards school and gaining knowledge, educational interests and plans for further education. The results indicated a trend of interrelatedness of cognitively and educationally favorable conditions within the family and positive attitudes towards school, attainment, high aspirations and cognitive and intellectual interests for out-of-school activities. Quilliams and Beran (2009) found that the more parents are involved in the school and actively promote learning at home, the higher the student's grades. In the same study, when children's perceptions were considered, those who perceived that their parents had positive attitudes towards education and took interest in the school had higher achievement.

Kabiru (2006) emphasizes the need for parents to instill discipline in their children at the family level.
He observes that parents contribute to children's indiscipline in many ways; by being bad role models and by avoiding parental responsibilities such as teaching their children good behaviour. This rebellion was manifested in the groups or gangs the youth formed to show solidarity in defying the school or societal expectations. Deepshika \& Bhanot (2011) in their study to assess family environment and its impact on their social emotional adjustment revealed that eight family environment factors, viz. cohesion, expressiveness conflict, acceptance and caring, independence, active-recreational orientation, organization and control together showed significant role in socioemotional and educational adjustment of the adolescent girls. When schools believe that lax parental discipline explains a child's misbehavior, educators are less likely to consider alternative explanations for the misbehavior and the full range of interventions that could be implemented at school (Greene, 2011).

\section{SUMMARY OF THE FINDINGS OF THE STUDY}

Parents attitude towards children's education had a significant relationship with student indiscipline in schools $(\mathrm{r}=.399, \mathrm{p}=.000)$. Hence the null hypothesis was therefore rejected at .05 level of significance.

\section{CONCLUSIONS}

From the findings of the study, it was clear that parents' attitude towards children's education had statistically significant influence on students' indiscipline. It can therefore be concluded that the more positive the attitude of parents towards children education, the less the level of indiscipline in schools.

\section{RECOMMENDATIONS}

The study further recommends that parents' should have more positive attitude towards a child's education. This can be realized through monitoring the academic performance of their children and taking keen concern on decline on the performance by engaging teachers.

\section{REFERENCES}

[1] Baumrind, D. (1966). Current patterns of parental authority.Developmental Psychology, 4(1), 1-103.

[2] Bogunovic B. and Polovina N.(2007). Educational-material context of the family and 
students' attitudes towards school in, Vol. 39, 99-144.

[3] Charles, L. (1995). Drug behaviour and modern society ( $2^{\text {nd }}$ Edition).Boston: Edward and Arnold.

[4] Cotton, K. (2000). Student Discipline and Motivation: Research Synthesis. Portland, Northwest Regional educational Laboratory.

[5] Darling.,\& Steinberg, L. (1993). Parenting style as context: An integrative model.Psychological Bulletin, 113 (3), 487-496.

[6] Deepshika, N. \& Bhanot, S. (2011). Role of family environment on socio-emotional adjustment of adolescent girls in rural areas of eastern Uttar Pradesh.Journal of Psychology, Vol2 (1), 53 - 56.

[7] Department of Education. (2004). Parental involvement: Title I, part A.Non-regulatory guidance. No Child Left Behind. USA.

[8] Desforges, C. \&Abouchaar, A. (2003).The impact of parental involvement, parental support and family education on pupil achievements and adjustment: A literature review.

http://www.dcsf.gov.uk/research/data/uploadfile s/RR433.pdf. Retrieved 18 November 2015

[9] Englund, M., Luckner, A., Whaley, G., \&Egeland, B. (2004). Children's achievement in early elementary school: Longitudinal effects of parental involvement, expectations and quality of assistance. Journal of Educational Psychology, Vol 94(4), 723-730.

[10]Epstein, J. L. \& Sheldon, S.B. (2001).Improving student attendance: Effects of family and community involvement. Washington, DC, Paper presented at the annual meeting of the American Sociological Association.

[11]Epstein, J.L. (2009). In school, family, and community partnerships: Your handbook for action (3rd ed.). Boston: Corwin Press.

[12] Eshiwani, G (2009). University Expansion in Eastern Africa: Challenges and Options in Higher Education. Inter-University Council for East Africa (IUCEA).Newsletter Vol. 39 pp 1722.

[13]Etizi, M. (2008).Effective student discipline: Methods for teachers. Nairobi: Shrend Publishers.

[14]Felix, T. (2011)."Leaving to be violent, the role of school in developing adolescent gendered behaviours."South African Journal of Education :EASA.33(3):385-398.
[15]Government of Kenya (2010).Vision 2030.Ministry of Education, Nairobi, Government printer.

[16]Greene, R. W. (2011). Behavior in school.Phi Delta Kappa, Vol. 26, 25-29.

[17]Griffin, G. (1994). School mastery: Straight talk about boarding schools management in Kenya. Nairobi: Lectern Publication Ltd.

[18]Grossnickle, D.R (1990). Prevent the discipline for effective teaching and learning. A source book for teachers and administrators. Virginia,Resten.

[19]Henderson, A. T. \&Mapp, K. L. (2002).A new wave of evidence: The impact of school, family, and community connections on student achievement. Texas, USA, Southwest Educational Development Laboratory.

[20]Hoover-Dempsey, K. V. \& Sandler, H. M. (1995). Parental involvement in children's education: Why does it make a difference? Teachers College Record, Vol. 97, 310-331.

[21]Hussain, S., \&Munaf, S. (2012).Perceived father acceptance-rejection in childhood and psychological adjustment in adulthood.International Journal of Business and Social Science. Vol 3(1), 149-156.

[22]Imber, M \& W. A. Neidt. (1990) Teacher participation in school decision making.Newsbury Park: Sage Publication Inc.

[23]Kabiru, L.K. (2006). A Study of Factors that Contributes to unrest in Secondary Schools in Kirinyaga District. (Unpublished M.Ed Research Project), Kenya, Kenyatta University.

[24]Khalid, S. (2004). Development and validation of the index of personal growth and the familial and dispositional predictors of personal growth (Unpublished PhD Thesis).National Institute of Psychology and centre of Excelance. Islamabad, Quaid-e- Azam University.

[25] Krejcie, R.\& Morgan, D. (1970). Determining sample sizes of research activities. Education and Psychological Measurement, Vol. 30, 607-610.

[26]Lochan, D. (2010) Students perceptions of indiscipline at three primary schools in one educational district in central Trinidad. (Unpublished M.A Thesis) University of the West Indies.University of West Indies.

[27]Lockheed, M.(1991) .Improving education. Education Review.Vol 16 (3)303-311.

[28]Masese, A (2007).A Study of the causes of Drug Abuse Among students in selected Secondary schools in Kisumu Municipality,Kenya.( 
Unpublished master's thesis) Kenya, University of Nairobi.

[29]MOEST (2014).Basic Education Statistical Booklet. Nairobi, UNICEF.

[30]Muchemi, N. C. (2006). Management of Student Riots in public secondary schools in Meru South District, (Unpublished Med Thesis) Nairobi, Kenyatta University.

[31] Muchemi, W. (2005).Education the living bud of a nation's development. Daily Nation,p23. June 22.

[32]Muscott, H. S. Szczesiul, S., Berk, B., Staub, K., Hoover, J., \& Perry-Chisholm, P. (2008). Creating home-school partnerships by engaging families in schoolwide positive behavior supports. Teaching Exceptional Children, Vol. 40(6), 7-14.

[33]Naivasha Sub-County Edication office (2015).

[34]Obeidat, O. M. and Al-Hassan, S. M. (2009). School-parent-community partnerships: The experience of teachers who received the queen Rania award for excellence in education in the Hashemite Kingdom of Jordan. The School Community Journal, Vol. 19(1), 119-136.

[35]Osher, D., Bear, G. G., Sprague, J. R., \& Doyle, W. (2010). How can we improve school discipline? Educational Researcher, Vol. 39(1), 48-58.

[36]Patall, E. A. Cooper, H., \& Robinson, J. C. (2008). Parent involvement in homework: A research synthesis. Review of Educational Research, Vol 78, 1039-1100.

[37]Quilliams, L \&Beran, T. (2009). Children at risk for academic failure: A model of individual and family factors. Exceptionality Education International, Vol. 19(2), 63-76.

[38]Republic of Kenya (2009).Ministry of Education: Education Management Information System, Facilitator Guide for EMIS Training. Nairobi: Ministry of Education.

[39]Republic of Kenya.(2012). Sessional Paper No. 14 of 2012 on realigning Education and Training to the Constitution of Kenya 2010 and Vision 2030 and beyond.Ministry of Education and Ministry of Higher Education, Science and Technology. Nairobi: Government Printers.

[40]Reutzel, R., \&Cooter, R. (1996).Teaching children to read: From basals to books. Englewood Cliffs, NJ: Prentice-Hall.

[41]Sanders, M. G. \& Sheldon, S. B. (2009).Principals matter: A guide to school, family, and community partnerships. Corwin: A SAGE Company.
[42]Tait, P. (1972). Effect of Circumstantial Rejection on Child's Behaviour. New Outlook for Blind.Vol 66, 139-149.

[43]Turnbull, P. (1983). "Systematic instruction of the moderately and severely handicapped" (2nd Ed), Englewood Cliffs, New Jersey; Merrill/Prentice Hall.

[44]Warnock, M. (1978).Special Education Needs.Report of the Committee of Enquiry into the Education of Handicapped Children and Young People. London, Warnock.

[45]Weiss, H., Caspe, M. \& Lopez, M.E. (2006).Family Involvement in Early Childhood Education.(Unpublished MA Theisi) Cambridge, Harvard Family Research Project. 